\title{
Screening of Cucumber Genotypes against Powdery Mildew
}

\author{
H. Parameshwar Naik* and Shripad Kulkarni \\ Department of Plant Pathology, College of Agriculture, UAS, Dharwad-580005, \\ Karnataka, India \\ *Corresponding author
}

\begin{tabular}{|l|}
\hline Key w ord s \\
Cucumis sativus L., \\
Cucumber \\
genotypes
\end{tabular}

\section{Introduction}

Cucumber (Cucumis sativa L.) is a popular fresh market vegetable preferred for several food stuffs and is cultivated throughout India. The total area under cucumber cultivation in India is 71000 hectare with a production of 1202000 tonnes with an average productivity of 16.92 tonnes (Anon, 2015-16). Powdery mildew is a serious disease and causes considerable yield loss to the number of cucurbitaceous crops grown in India. Its distribution and relative occurrence varies throughout the world. Most of the cucurbits
(Cucumis sativus L.) is one of the oldest cultivated vegetable crops belongs to the family cucurbitaceous with 7 pairs of chromosomes and several distinct morphological features stands apart from other species with 12 pairs of chromosomes which are indigenous to tropical Africa. Now a day's powdery mildew has become a major disease in cucumber, since there is no detailed quantitative information on effective management of the disease resistance genotypes plays an important role to combat against pathogen. This can be used as one of the strategy for the management of the disease. Twenty three genotypes were screened against $E$. cichoracearum under natural epiphytotic conditions in the field to identify the resistance source during late kharif 2016 none were found to be immune or Malini, Shirakawa, Yummy, Kareena, Green long, Ajeeth-99, White long, Encounter-962, Shalini, Ranebennur local and Sarpan hybrid were found to be moderately resistant with five grade and five genotypes Viz., Chetak, Gullakai, Khushi, Sribasava and Harini were and chitra showed highly susceptible reaction with maximum reaction of nine grade. 
disease as its occurrence and incidence assumes greater significance resulting in reduction of fruit yield. Powdery mildew and downy mildew together causes up to 50-70 per cent a loss (Sitterly, 1972 and Awad, 2000).

The most cost effective way of combating diseases is the production of cucumber hybrids with multiple disease resistance. Due to the unfavorable climatic conditions, resistant varieties are becoming susceptible and also not showing consistent resistance. A few commercial cucumber varieties or hybrids resistant to powdery mildew and downy mildew diseases are currently available in India. Primary importance in disease management is host plant resistance. To achieve this, in the present study screening of cucumber genotypes has been taken in late kharif during 2016.

\section{Materials and Methods}

A field experiment was conducted to find out the resistance source against cucumber powdery mildew. Totally twenty three genotypes were collected and screened against powdery mildew under artificial epiphytotic condition. Each genotype was sown in three rows of five meter length during the late kharif 2016 at MARS, Dharwad. The disease severity was recorded using 0-9 scale by randomly selecting five plants in each genotype (Mayee and Datar, 1986). Based on their reaction genotypes were categorized into immune, resistant, moderately resistant, moderately susceptible, susceptible and highly susceptible.

Five plants were randomly selected and powdery mildew severity was recorded by following 0-9 scale through visual observation (Mayee and Datar, 1986) as given below.

\section{Disease scoring scale}

\section{Per cent disease index (PDI)}

The severity of cucumber powdery mildew was recorded by using 0-9 scale developed by Mayee and Datar (1986) as given below:

\section{Results and Discussion}

Twenty three genotypes were screened against E. cichoracearum under artificial epiphytotic conditions in the field to identify the resistance source during late kharif 2016 as described in "Material and Methods" and results are presented in Table 1 . The results from the experiment revealed that, out of twenty three genotypes screened, none was found to be immune or and resistant. However, fifteen genotypes viz., Swathi, BSS949, JK-special, Mahy Sylvia, Malini, Shirakawa, Yummy, Kareena, Green long, Ajeeth-99, White long, Encounter-962, Shalini, Ranebennur local and Sarpan hybrid were found to be moderately resistant with five grade and five genotypes Viz., Chetak, Gullakai, Khushi, Sribasava and Harini were found to be moderately susceptible with seven grade and Mangalore local, Dharwad green and chitra showed highly susceptible reaction with maximum reaction of nine grade.

The management of the disease through host plants resistance has been the best choice in all the disease management programmes. Utilization of resistant cultivars in farming system is the most simple, effective and economical method in the management of disease. Besides this, these resistant cultivars conserve natural resources and reduce the cost, time and energy compared to the other methods of disease management.

Experiment on screening of cucumber genotypes was conducted during late kharif 2016. Twenty three genotypes were screened against E. cichoracearum under artificial epiphytotic conditions among them none of the genotypes shown immune or resistant, however, fifteen genotypes Viz., Swathi, BSS949, JK-special, Mahy Sylvia, Malini, Shirakawa, Yummy, Kareena, Green long, 
Ajeeth-99, White long, Encounter-962, susceptible genotypes such as Mangalore Shalini, Ranebennur local and Sarpan hybrid local, Dharwad green and Chitra, showed were found moderately resistant and five genotypes viz., Chetak, Gullakai, Khushi, Sribasava and Harini were moderately highly susceptible reaction and these work are lined with Gondi (2015) Pitchaimuthu et al., (2012) (Table 2).

Table.1 Reaction of cucumber genotypes against powdery mildew caused by Erysiphe cichoracearum (0-9 scale)

\begin{tabular}{|c|c|c|c|}
\hline SL. No. & Genotype & Maximum grade observed & Reaction type \\
\hline 1 & Swathi & 5 & MR \\
\hline 2 & BSS-949 & 5 & MR \\
\hline 3 & JK-special & 5 & MR \\
\hline 4 & Mahy sylvia & 5 & MR \\
\hline 5 & Chetak & 7 & MS \\
\hline 6 & Mangalore local & 9 & $\mathrm{HS}$ \\
\hline 7 & Malini & 5 & MR \\
\hline 8 & Shirakawa & 5 & MR \\
\hline 9 & Dharwad green & 9 & $\mathrm{HS}$ \\
\hline 10 & Yummy & 5 & MR \\
\hline 11 & Kareena & 5 & MR \\
\hline 12 & Green long & 5 & MR \\
\hline 13 & Ajeeth & 5 & MR \\
\hline 14 & White long & 5 & MR \\
\hline 15 & Gullakai & 7 & MS \\
\hline 16 & Encounter-962 & 5 & MR \\
\hline 17 & Chitra & 9 & $\mathrm{HS}$ \\
\hline 18 & Khushi & 7 & MS \\
\hline 19 & Shalini & 5 & MR \\
\hline 20 & Sribasava & 7 & MS \\
\hline 21 & Ranebennur local & 5 & MR \\
\hline 22 & Harini & 7 & MS \\
\hline 23 & Sarpana hybrid & 5 & MR \\
\hline
\end{tabular}


Table. 2 Grouping of cucumber genotypes based on reaction against powdery mildew caused by Erysiphe cichoracearum

\begin{tabular}{|c|c|c|c|c|}
\hline Grade & Reaction & $\begin{array}{l}\text { Per cent } \\
\text { infection }\end{array}$ & Entries & $\begin{array}{c}\text { No. of } \\
\text { genotypes }\end{array}$ \\
\hline 0 & I & 0 & - & 0 \\
\hline 1 & HR & Up to 1 & - & 0 \\
\hline 3 & $\mathrm{R}$ & $1-10$ & - & 0 \\
\hline 5 & MR & $11-25$ & $\begin{array}{l}\text { Swathi, BSS-949, JK-special, Mahy Sylvia, } \\
\text { Malini, Shirakawa, Yummy, Kareena, Green } \\
\text { long, Ajeeth-99, White long, Encounter-962, } \\
\text { Shalini, Ranebennur local, Sarpana hybrid. }\end{array}$ & 15 \\
\hline 7 & MS & $26-50$ & Chetak, Gullakai, Khushi, Sribasava, Harini. & 5 \\
\hline 9 & HS & $\begin{array}{c}\text { More than } \\
51\end{array}$ & Chitra, Dharwad green, Mangalore local & 3 \\
\hline
\end{tabular}

List of genotypes used for screening

\begin{tabular}{|c|c|c|c|}
\hline Sl. No & Genotypes & Source & Place \\
\hline 1 & Swathi & Bioseeds Pvt. Ltd. & Hyderabad \\
\hline 2 & BSS-949 & Kalash seeds pvt. Ltd & Jalna, Maharashtra \\
\hline 3 & JK-special & Agro inputs Pvt. Ltd. & Ahmedabad \\
\hline 4 & Mahy sylvia & Mahyco seeds Pvt. Ltd. & Jalna, Maharashtra \\
\hline 5 & Chetak & Trusted seeds Pvt. Ltd. & New Delhi \\
\hline 6 & Mangalore local & Keyonics seeds Pvt. Ltd. & Bangalore \\
\hline 7 & Malini & Monsanto Pvt. Ltd. & Ahmedabad \\
\hline 8 & Shirakawa & Sakata seeds Pvt. Ltd. & Gurugram, Haryana \\
\hline 9 & Dharwad green & Nadakatti seeds Pvt. Ltd. & Dharwad \\
\hline 10 & Yummy & Bioseeds Pvt. Ltd. & Hyderabad \\
\hline 11 & Kareena & Nuziveedu seeds Pvt. Ltd. & Hyderabad \\
\hline 12 & Green long & Ceres Pvt. Ltd. & Kolkata, West Bengal \\
\hline 13 & Ajeeth-99 & Ajeeth seeds Pvt. Ltd. & Aurangabad, Maharashtra \\
\hline 14 & White long & Keyonic seeds Pvt. Ltd. & Bangalore \\
\hline 15 & Gullakai & Mrutyunjaya seeds Pvt. Ltd. & Dharwad \\
\hline 16 & Encounter-962 & East west seeds India Pvt. Ltd. & Aurangabad, Maharashtrc \\
\hline 17 & Chitra- & RASI seeds Pvt. Ltd. & Hyderabad \\
\hline 18 & Khushi & Dhanvi seeds Pvt. Ltd. & Hyderabad \\
\hline 19 & Shalini & Ocean crop science Pvt. Ltd. & New Delhi \\
\hline 20 & Sribasava & Tanindo seeds Pvt. Ltd. & Kodigehalli, Bangalore \\
\hline 21 & Ranebennur local & Keyonic seeds & Bangalore \\
\hline 22 & Harini & Noble seeds Pvt. Ltd. & Bangalore \\
\hline 23 & Sarpana hybrid & Sarpan hybrid seeds Pvt. Ltd. & Dharwad \\
\hline
\end{tabular}




\section{Per cent disease index (PDI)}

\begin{tabular}{|c|l|}
\hline Score & \multicolumn{1}{|c}{ Description } \\
\hline 0 & No symptom of powdery mildew on leaves. \\
\hline 1 & Small scattered powdery mildew specks covering 1\% or less leaf area. \\
\hline 3 & Small powdery lesions covering 1-10\% of leaf area. \\
\hline 5 & Powdery lesions enlarged covering 11-25\% of leaf area. \\
\hline 7 & Powdery lesions coalesce to form big patches covering 26-50\% leaf area. \\
\hline 9 & Big powdery patches covering $51 \%$ or more of leaf area and defoliation occur \\
\hline
\end{tabular}

Per cent disease index (PDI) was calculated by using formula given by Wheeler (1969).

The results of screening of cucumber genotypes against powdery mildew which reveals that, out of twenty three genotypes screened under artificial epiphytotic condition, none of them were found immune and resistant, however, fifteen genotypes viz., Swathi, BSS-949, JK-special, Mahy Sylvia, Malini, Shirakawa, Yummy, Kareena, Green long, Ajeeth-99, White long, Encounter-962, Shalini, Ranebennur local and Sarpan hybrid were found to be moderately resistant and five genotypes viz., Chetak, Gullakai, Khushi, Sribasava and Harini were found to be moderately susceptible. With 9 grades in 0-9 scale genotypes such as Mangalore local, Dharwad green and Chitra showed highly susceptible reaction.

\section{References}

Anonymous, 2015-16, Handbook of horticulture statistics, GOI, Ministry of agriculture. Department of agricultural sciences and co-operation. New Delhi. pp: 14-16.
Awad, N. G. H., 2000, Reaction of some cucurbits against physiological and histopathological changes. Arab Univ. J. Agric. Sci., 8: 829-851.

Gondi, S., 2015, Evaluation of oriental pickling melon genotypes for northern dry of Karnataka. M. Sc (Hort.) Thesis, Univ. Horti. Sci., Bagalkot, Karnataka. (India).

Mayee, C. D. and Datar, V. V., 1986, Phytopathopmety. Technical Bulletin-1 (special bulletin-3), Marathwada Agricultural University, Parbhani, Maharasthra, India, PP: 29.

Pitchaimuthu, M. K., Souravi, Ganeshan, G., Kumar, S. and Pushpalatha, R., 2012, Identification of sources of resistance to powdery and downy mildew diseases in cucumber (Cucumis sativus L.) Pes. Manag. Horti. Ecosys., 18 (1): 105-107.

Sitterly, W. R., 1972, Powdery Mildews of Cucurbits. In: The Powdery Mildews, D. M Spencer ed. Academic Press Inc. Ltd., New York. PP: 359-379.

\section{How to cite this article:}

Parameshwar Naik H. and Shripad Kulkarni. 2018. Screening of Cucumber Genotypes against Powdery Mildew. Int.J.Curr.Microbiol.App.Sci. 7(04): 414-418. doi: https://doi.org/10.20546/ijcmas.2018.704.047 